\title{
On the effect of audit committee characteristics on corporate governance good practices index. Fresh evidence from Sudan listed firms
}

\author{
Hussein Mohamed Elnafabi \\ CBE, Accounting Department Qassim University, Saudi Arabia
}

Correspondence Author: Hussein Mohamed Elnafabi, CBE, Accounting Department Qassim University, Saudi Arabia.

Received date: 18 March 2019, Accepted date: 5 May, Online date: 25 May 2019

Copyright: (C) 2019 Hussein Mohamed Elnafabi et al., This is an open-access article distributed under the terms of the Creative Commons Attribution License, which permits unrestricted use, distribution, and reproduction in any medium, provided the original author and source are credited.

\begin{abstract}
The paper aims to study the effect of audit committee characteristics on the effectiveness of corporate governance practices among Sudanese public firms. We use a survey to construct an index of corporate governance practices effectiveness and an OLS regression method was used in order to test the effect of the main audit committee characteristics namely, the committee size, the committee experience, the committee education and the committee professional certificates on corporate governance good practices. The effect of auditors' age on corporate governance practices effectiveness was also discussed.
\end{abstract}

Keywords: Audit committee; corporate governance practices effectiveness index; Sudanese public firms

\section{INTRODUCTION}

In the late nineties of the twentieth century and the beginning of the 21th century, a number of major companies such as Enron the power company, the telecommunications company WorldCom, RBS, Northern Rock, Oceanic Bank, Intercontinental Bank, and other companies in the US and other countries, have collapsed which made a big shook in investors' confidence, and raised questions about how this has allowed large companies to such collapse (Fredrick and Gedion, 2014). In 2002, after these major corporate failures occurred, the significance of good corporate governance hit the world headlines. At that time the USA president Bush noted that "if nothing is done our debt problem will continue to get worse, millions of jobs will continue to leave our country, small companies will continue to be suffocated, middle-class companies will continue to collapse, and poverty in the USA will continue to explode" (Fredrick and Gedion, 2014). These events brought about a heightened public awareness of corporate governance issues. Also, the global economic' crunch, which began in 2007 added further strands to corporate governance practices and policies (Omolaye and Jacob, 2017).

These serious events which occurred in the USA and other countries, have shown critical role which should be played by the boards of directors in strengthening effective corporate governance, especially as they bare the ultimate responsibility for internal control systems in their companies, where the internal audit function plays a key role in assisting the boards of directors in carrying out assignments governance essentially responsible for them, which they should have to answer this question: are the board of directors and the audit committee emanating from it convinced that the internal audit functions effectively and the efficiently? (Jabali et al., 2011).

Internal auditing can be considered as a key feature on resolving the financial crises and management conflicts and so it can affect the corporate governance practices and it can also increase their effectiveness. In fact, internal auditing is seen as a key factor for the success of any organization, and it has been recognized as an indispensable factor in ensuring sound financial reporting and deterring misappropriations of capital in an organization. This study aims to examine the role of internal auditing in enhancing good corporate governance for companies listed in the Khartoum stock exchange. The study conducted in The Sudan region. Sample of study was based on internal auditors, who were working in companies listed in the Khartoum stock exchange.

The role of internal audit and especially the audit committee is for interest for the Sudanese firms. The financial market in Sudan is still less developed and so we need efforts to increase the investors' confidence level. The corporate governance so should be activated and it should also be effective to reduce the corruption level. 
Citation: Hussein Mohamed Elnafabi, et al., On the effect of audit committee characteristics on corporate governance good practices index. Australian Journal of Basic and Applied Sciences, 13(5): 55-59. DOI: 10.22587/ajbas.2019.13.5.6

In fact, despite the production of oil since 2000, in addition to many other sources of national wealth, Sudan is classified, according to many international organizations, amongst the very poor and most corrupt countries in the world (CPI, 2017; Economic Freedom Index, 2016, World Bank, 2017). The poor public financial management system and financial controls in the Sudan, in addition to the absence of transparency in the functioning of government, the deficiencies of prosecuting agencies, the ineffectiveness of procurement and audit, shortage of qualified accounting and auditing staff, and low salary levels of public sector employees are the major factors which facilitate corruption and misuse of the limited public funds in the Sudan (General Audit Chamber, 2017, Elnafabi, 2010, Logune, 2006).

After the secession of southern Sudan, which was on July 9, 2011, the budget of northern Sudan lost about 36\% of its revenues due to the secession of the south, which was about $73 \%$ of Sudanese oil production, which was one of the main sources of foreign exchange (Elnafabi, 2016). This situation made it necessary for the Sudanese economy to rely on other sources that contribute effectively to support the Sudanese economy and contribute to the provision of foreign exchange. One of the most important of these sources is the private sector institutions and so it's time to improve the control mechanism especially for the private public firms.

\section{HYPOTHESES DEVELOPMENT}

To draw the story between the audit committee characteristics and corporate governance practices we will discuss in this section the effect of each committee characteristics and its potential effect on corporate governance practices. Namely, we will explore the effect of committee size, experience and knowledge. By the end of this section we also advance theoretical on the potential effect of auditor professional certificate on corporate governance effectiveness.

\subsection{Audit committee size}

The audit committee size is one of the most determinants of committee performance. The effect of audit committee size seems having a mitigate impact on its performance. Jensen (1993) argue that streamlined boards can operate more effectively in maintaining management in general and can be extended to audit committee size. This means that the audit committees with small size are more effective and this can increase the good practices of corporate governance since auditors will act more effectively. The superiority of smaller audit committee size can be justified by the fact in the case of large audit committee size firms are more likely to include outside directors on audit committee beyond the mandated minimum requirements, which enhances audit effectiveness (Beasley and Salterio , 2001). Empirical finding by Hillman and Dalziel (2003) show that a large auditing committee can eliminate the monitoring process and reduce the firm performance. The negative influence of committee size on firm performance is also supported by Vafeas (1999).

In contrast, a wave of research papers concludes that large audit committees are more effective and help increasing firms performance (Reddy et al., 2010). The effect of committee size can largely affect the corporate governance practice. The audit committee aims to provide a connection between corporate governance and the auditor (Collier and Gregory, 1996). The audit committee is a central pillar since its role is to assess and review external and internal information, ensure financial reporting, provide a control system and improve the connection between an external and internal auditor (Nacd, 2000).

Audit committee with small size can be more effective and it can facilitate the application of corporate governance good practices. The effect of audit committee size is similar to that of the board of directors (Ben Mohamed, 2014; Baccar et al., 2013; Ben Mohamed and Shehata, 2017).

$H_{1}$ : The audit committee size can negatively affect the corporate governance good practices index.

\subsection{The audit committee financial and accounting education}

In the last five years there is a wave of study concentrating on the effect of managers, as well as auditors, education on their management style (Schoar, 2003; Ben Fatma et al, 2015; Ben Mohamed et al., 2012, 2014 a, 2014b, Baccar et al., 2013, Ben Mohamed and Jarboui, 2016). The financial and accounting expertise can limit routine earnings management, including lower abnormal accruals and higher accrual quality (Carcello et al., 2006). Among a large sample of American firms, Ben Mohamed et al., 2014) demonstrate that the CEOs financial education can reduce the investment cash-flow sensitivity and so increase the management quality. Ben Fatma et al. (2015) show that an entrepreneur's education can increase small firms' technical efficiency. In the same line of research Ben Mohamed et al., (2015) conclude that the CEOs education contributes to the increasing the technical efficiency of transport firms.

The financial and accounting expertise can also reduce the weaknesses of internal controls and so enhancing the good corporate governance practices (Krishnan, 2005). By translation of these cited works on the audit committee, we predict that the financial and accounting expertise have explanatory power, and it can increase the corporate governance good practices index. Then we can formulate the potential effect of audit committee financial and accounting expertise on corporate governance as the following:

$\mathrm{H}_{2}$ : The audit committee financial and accounting expertise can positively affect the corporate governance good practices index.

\subsection{The audit committee experience}

One of the most studied characteristics in the board of directors and other related committees is the experience. This variable refers to the number of years that the audit committee members act as an internal auditor. This variable is an important dimension of the audit committee effectiveness (Robertson and Deakin, 1997). For audit committee members, experience refers to the amount of time spent working in areas related to assigned corporate oversight responsibilities. The experience seems to have a positive effect on committee decisions and activities. It can increase the effectiveness of the committee decision, and this can 
Citation: Hussein Mohamed Elnafabi, et al., On the effect of audit committee characteristics on corporate governance good practices index. Australian Journal of Basic and Applied Sciences, 13(5): 55-59. DOI: 10.22587/ajbas.2019.13.5.6

increase the probability that a firm can apply good corporate governance practices. The hypothesis that links the audit committee experience and the corporate governance good practices can be formulated as follow:

$\mathrm{H}_{3}$ : The audit committee experience can positively affect the corporate governance good practices index.

\subsection{The audit committee professional certificates}

In this paper, we introduce the effect of professional certificates as essential characteristics of the audit committee on corporate governance good practices index. In a general way, we predict that if the audit committee members have a professional certificate such as SOCPA, CPA, CII should be more productive and they can improve the role of audit committee a thing that can enhance the corporate governance good practices. Our fourth hypothesis can be formulated as follow:

$\mathrm{H}_{3}$ : The audit committee professional certificates can positively affect the corporate governance good practices index.

\section{METHODOLOGY AND DATA COLLECTION}

The empirical part of this study based on the data collected through the questionnaire, which has been developed by the researcher and distributed to the chief internal auditors in companies listed in the Khartoum stock exchange. Sixty questionnaires have been distributed through the direct handle. This method was chosen because the personal delivery and follow-up was perceived as likely to generate a higher response rate. All the sixty questionnaires have been collected with a response of $100 \%$. After collecting data from respondents, it was analyzed to examine the role of internal auditing in enhancing good corporate governance in companies listed in the Khartoum stock exchange. The questionnaire is divided into two categories. The first section of the questionnaire intends to collect the general information about the respondents and then, the second section presents the internal auditors' responsibility for the evaluating and examining the quality of corporate governance in the companies listed in the Khartoum stock exchange.

We test the questionnaire validity using Cronbach Alpha, which is around $90 \%$. This means that there is a strong internal consistence between items and there is a strong validity. The dependent variable is the corporate governance good practices index [CGI], which is calculated on the basis of 15 questions that describes the good corporate governance practices. For each question we propose a description of a good practice act and we use a Likert scale so that the weight of each proposition is between 0 and 5. Finally, we calculate the full score of each respondent and then we divide by the maximum weight, our index so will vary between 0 and 1 .

Our independent variables are successive; the committee size (CSize), the committee experience (CExp); the committee education (Educ), the professional committee certificate (PCert).

The committee size is measured using the number of auditors in the committee. The committee experience is measured using the mean of the number of years of experience of each member in the committee. The committee education is a binary variable which takes one if the audit committee members have a financial and accounting education. Finally, the professional committee certificates represent the average of professional certificates of audit committee members. Our model regress directly the corporate governance good practices index with the independent variables and it is a linear function:

$C G I_{i}=\gamma_{0}+\gamma_{1}$ CSize $_{i}+\gamma_{2} C \operatorname{Exp}_{i}+\gamma_{3} C E d u_{i}+\gamma_{4}$ Pert $_{i}+\varepsilon_{i}$

\section{RESULTS}

Using the MCO estimation, our results indicate that the proposed audit committee characteristics are for interest and can explain the variation of corporate governance good practices. Our result highlights that audit committee size have a positive influence on corporate governance good practices index. This relationship is significant at the five percent level of signification. This result corroborates previous studies that indicate that the large audit committees are more effective than small committees.

Regarding the effect of auditors' education on corporate governance good practices, our results show that a specific education on finance and accounting of the committee members can increase the index. This means that the financial and accounting education contributes to the effectiveness of audit committee activities, and this result is significant in the five percent level.

The positive effect of audit committee experience and the professional certificates are significant, respectively at the first and third level of significance. These findings are in coherence with our theoretical predictions except the hypothesis that predicts a negative effect of audit committee size on corporate governance good practices index.

Table 1: Descriptive Statistics

\begin{tabular}{|c|c|c|c|c|c|}
\hline & $\mathrm{N}$ & Minimum & Maximum & Mean & Std. Deviation \\
\hline CGINDEX & 46 & .23 & .98 & .7660 & .15924 \\
\hline EDUC & 46 & .00 & 1.00 & .5870 & .49782 \\
\hline PROFESS & 46 & .00 & 1.00 & .5870 & .49782 \\
\hline EXPER & 46 & 1.00 & 30.00 & 13.5870 & 8.45005 \\
\hline COMSIZE & 45 & 1.00 & 12.00 & 4.9778 & 4.16964 \\
\hline
\end{tabular}


Citation: Hussein Mohamed Elnafabi, et al., On the effect of audit committee characteristics on corporate governance good practices index. Australian Journal of Basic and Applied Sciences, 13(5): 55-59. DOI: 10.22587/ajbas.2019.13.5.6

Table 2 : Model Summary

\begin{tabular}{|c|c|c|}
\hline & $\gamma$ & Sig \\
\hline (Constant) & .629 & .065 \\
\hline EDUC & .122 & .046 \\
\hline PROFESS & .011 & .048 \\
\hline EXPER & .004 & .003 \\
\hline COMSIZE & 0.36 & .006 \\
\hline Adjusted R-square & \multicolumn{2}{|c|}{0.42} \\
\hline
\end{tabular}

\section{MANAGERIAL IMPLICATIONS}

Regarding our empirical findings, Sudanese firms are invited to adopt an optimal audit committee structure. This is by opting for large audit committees than small committees. The audit committee composition should be improved by the nomination of auditors with good experience, a financial or/and accounting education and professional certificates. Sudanese firms should improve good corporate governance practices by enhancing the audit committee activities. The internal control will be effective if only it is structured optimally.

\section{REFERENCES}

Abdalla, A. M. (2010) "Corporate Governance with Special Reference to Sudan," A Thesis Submitted to the University of Khartoum in Partial Fulfillment of the Requirement for the Degree of LL.M, University of Khartoum, Sudan, pp. 39-41.

Baccar, A, Ben Mohamed, E and Bouri, A (2013). Managerial optimism, overconfidence, and board characteristics: towards a new role of corporate governance. Australian journal of basic and applied sciences 7 (7), 287-301

Beasley, M.; Salterio, S. The relationship between board characteristics and voluntary improvements in audit committee composition and experience. Contemp. Account. Res. 2001, 18, 539-570.

Ben Fatma, E., Ben Mohamed, E., Boudabbous, S., (2015). Does entrepreneur dispositional optimism bias affect small firms' technical efficiency. International Journal of Entrepreneurship and Small Business 24 (3), 302-321

Ben Mohamed, E., Fairchild, R., Bouri, A.,( 2014a). Investment cash flow sensitivity under managerial optimism: new evidence from NYSE panel data firms. J. Econ. Financ. Adm. Sci. 19 (36), 11-18.

Ben Mohamed, E., Mohamed Naceur, R., Baccar, A., Bouri, A., 2014b. CEO’s personal characteristics, ownership and investment cash flow sensitivity: evidence from NYSE panel data firms. J. Econ. Financ. Adm. Sci. 19 (37), 98-103.

BM Ezzeddine, S Jarboui (2017). Do Corporate Governance Mechanisms Affect Public Transport Firm Value?. Journal of the Knowledge Economy, 8(3), 916-928.

Cadbury, A., (1992), "The Financial Aspects of Corporate Governance: A Report of the Committee on Governance", Gee \& Co London.

Circular No. (9/2005) issued Central Bank of Sudan, Banking Supervision department Regulations and Circulars, $4^{\text {th }}$ October 2005.

Dunlop, A., (1998), "Corporate Governance and Control", London, CIMA Publishing.

EB Mohamed, A Baccar, R Fairchild, A Bouri (2012) Does corporate governance affect managerial optimism? Evidence from NYSE panel data firms International Journal of Euro-Mediterranean Studies. 5(1), 41-56.

EB Mohamed, MA Shehata (2017). R\&D investment-cash flow sensitivity under managerial optimism. Journal of Behavioral and Experimental Finance 14, 1-4

Elnafabi, Hussein Mohamed (2010), " Public Financial Management in Sudan", International Journal of Government Financial Management (IJGFM); 2010, Vol. X, Number 1, pp. 42-54, Virginia, USA. http://www.icgfm.org/journal/201001_IJGFM.pdf

Elnafabi, Hussein Mohamed (2016), " The Importance of using Planning Budgets in Planning, Monitoring and Performance Evaluation in the Private Sector Companies in the Sudan, and the Extent of Participation of Employees in the Executive Administrations in the Preparation and Implementation", Journal of Accounting Thought, Accounting and Auditing Department, Ain Shams University, Egypt, Issue 20 (4), pp. 461-510.

Fredrick, O. and Gedion O., (2014), "The Role of Internal Audit in enhancing Corporate Governance for Companies Listed at the Nairobi Stock Exchange", Research Journal of Finance and Accounting, Vol. 5, No. 3, pp.56-61.

General Audit Chamber (Sudan), the Annual Audit Report, 2017.

Hillman, A., Dalziel, T. (2003), Boards of Directors and Firm Performance: Integrating Agency and Resource Dependence Perspectives. Academy of Management Review, 28 (3): 383-396.

Jabali, M., Abdalmanam, O. and Ziadat, K., (2011), "Internal Audit and its Role in Corporate Governance", Middle eastern Finance and Economics, Issue 11, pp. 161-176.

Jensen, M. C. (1993) The modern industrial revolution, exit, and the failure of internal control systems, Journal of Finance, 48, 831-880.

John, K., and Senbet, L., (1998), "Corporate Governance and Board Effectiveness", Journal of Banking and Finance, 22, pp. 371403. 
Citation: Hussein Mohamed Elnafabi, et al., On the effect of audit committee characteristics on corporate governance good practices index. Australian Journal of Basic and Applied Sciences, 13(5): 55-59. DOI: 10.22587/ajbas.2019.13.5.6

Karagiorgos, T., Drogalas, G., Christodoulou, P. and Pazarskis, M., (2006), "Conceptual Framework, Development Trends and Future Prospects of Internal Audit: Theoretical Approach", $5^{\text {th }}$ Annual Conference, Hellenic Finance and Accounting Association (H.F.A.A.), Thessaloniki, Conference Proceedings.

Karagiorgos, T., Drogalas, G., Gotzamanis, E. and Tampakoudis, I. (2010), "Internal Auditing as an Effective Tool for Corporate Governance", Journal of Business Management, Vol. 2, No. 1, p. 17.

Kidaouene, Abou Bakr E and Gourine, Haj K. (2017); "The Role of the Internal Audit Function in the Activation of Corporate Governance: According to the New Standards of Internal Audit 2017"; The Laws and Scientific Humanitarians Journal, University of Chlef, Algeria, Vol. 10, No. 31 (2), pp. 424-435.

Logune, A. T. (2006), “Reporter's Notebook: Sudan”, Global Integrity, 2006 Country Reports, Washington, DC, 2006.

Mohamed, E.B. and M.A. Shehata, (2017) R\&D investment cash flow sensitivity under managerial optimism. Journal of Behavioral and Experimental Finance. 14: p. 1-4.

Nagy and Cenker (2002)

Omolaye, KE and Jacob, RB (2017); "The Role of Internal Auditing in Enhancing Good Corporate Governance Practice in an Organization"; International Journal of Accounting Research, Vol. 6, pp. 1-8.

Omolaye, KE and Jacob, RB, (2017), "The Role of Internal Auditing in Enhancing Good Corporate Governance Practice in an Organization", International Journal of Accounting Research, Vol 6, Issue 1, p. 2.

Papadatou, Th., (2005), "Internal and External Control of Joint Stock Companies", Sakoulas ed., Greece.

Reddy, K., Locke, S., \& Scrimgeour, F. (2010). The efficacy of principle-based corporate governance practices and firm financial performance: An empirical investigation. International Journal of Managerial Finance, 6(3), 190-219.

Rezaee, Z., (1996), "Improving the Quality of Internal Audit Functions Through Total Quality Management", managerial Auditing Journal, MCB University Press, 11(1), pp. 30-34.

Sarens, G. and De Beelde, I., (2006), "The Relationship Between Internal Audit and senior Management: A qualitative Analysis of Expectations and Perceptions", International Journal of Auditing, Vol. 10, No. 3, pp. 219-241.

Shleifer, A. and Vishny, RW, (1997), "A Survey of Corporate Governance ", The Journal of Finance, L11.

Skinner, D. and Spira, L.F. (2003); "Trust and Control-a Symbiotic Relationship?" Corporate Governance, Vol. 3, No. 4, pp. 2835.

Sternberg, E., (1998), "Corporate Governance and Accountability in the Marketplacy", London, The Institute of Economic Affairs.

Tabara, N. and Ungureanu, M., (2012). "Internal Audit and its Role in Improving Corporate Governance systems", Annales Universitatis Apulensis Series Oeconomica, 14(1), pp. 139-145.

The Institute of Internal Auditors, (1999), "Definition of Internal Auditing", the Institute of Internal Auditors, Altamonte Spring, FL.

The Institute of Internal Auditors, (2016), "International Standards for the Professional Practice of Internal Auditing", Revised: October 2016, p. 21.

The Institute of Internal Auditors-UK, (1991), "Standards and Guidelines for the Professional Practice of Internal Auditing", IIAUK ed. (Statement of Responsibilities).

Vafeas, N. (1999). Board meeting frequency and firm performance. Journal of Financial Economics, 53(1), 113-142. 